\title{
Growth and reproduction in the Antarctic brooding bivalve Adacnarca nitens (Philobryidae) from the Ross Sea
}

\author{
Nicholas D. Higgs · Adam J. Reed • Rachel Hooke • \\ David J. Honey · Olaf Heilmayer · Sven Thatje
}

Received: 4 September 2008/Accepted: 1 February 2009/Published online: 20 February 2009

(C) Springer-Verlag 2009

\begin{abstract}
We present information on the reproductive biology, population structure, and growth of the brooding Antarctic bivalve Adacnarca nitens Pelseneer 1903, from the Ross Sea, Antarctica. Individuals ranging from 0.85 to $6.00 \mathrm{~mm}$ were found attached to a hydrozoan colony. This species shows low fecundity and large egg size, common to other brooding species. The minimum size at which oogenesis was detected was $2.3 \mathrm{~mm}$ and the minimum size at which brooding was evident was $3.9 \mathrm{~mm}$. Embryos of a full range of developmental stages were brooded simultaneously in females. The population showed a log-normal distribution and results suggest non-periodic reproduction with continuous embryonic development. The reproductive traits of A. nitens are discussed in the context of circumAntarctic species distribution and limitations to dispersal in brooding benthic invertebrates.
\end{abstract}

\section{Introduction}

Brooding is a common mode of reproduction in small-sized bivalves, no matter where they live (Ramirez Llodra 2002; Ripley and Caswell 2008). However, brooding appears to be a quite successful and common strategy, where environmental conditions put constrains on the availability of

Communicated by M. Byrne.

N. D. Higgs - A. J. Reed - R. Hooke - D. J. Honey ·

O. Heilmayer $\cdot$ S. Thatje $(\square)$

School of Ocean and Earth Science, National Oceanography

Centre Southampton, University of Southampton,

European Way, Southampton SO14 3ZH, UK

e-mail: svth@noc.soton.ac.uk energy to adults and/or larvae (Galley et al. 2005). This becomes particularly important in cold water and foodlimited environments, such as the deep sea and the polar oceans, where a mismatch between the short periods of food availability and prolonged developmental times as a result of low temperatures select against planktotrophic larvae (Mileikovsky 1971; Arntz and Gili 2001; Thatje et al. 2005). The energetic constraints set under such conditions would seem to favour the protected development (e.g. brooding) as the most efficient method of overcoming larval mortality in comparison to free development (for discussion see Heilmayer et al. 2008). Increasing the proportion of reproductive effort invested into a single offspring may improve its chance of survival, but at the expense of a reduced fecundity (Vance 1973).

Within the Antarctic context, a prevalence of brooding species is striking for some invertebrate groups and especially bivalves, although some of the most abundant species display planktotrophy (Poulin et al. 2002; Thatje et al. 2005). Several theories have been put forward to explain the particular success of brooding in the cold (Poulin et al. 2002; Pearse and Lockhart 2004). They emphasise the need to consider whole clades of species in their evolutionary context because of phyletic constraints on reproductive adaptations (e.g. Gallardo and Penchaszadeh 2001; Thatje et al. 2003). While the evolution of brooding has occurred independently 14 times in the echinoids (Emlet 1990), taxa such as the bivalve family, Philobryidae appear to have speciated to form large clades made up entirely of brooding species. This family is particularly specious (Arntz et al. 1997), and abundant (Jarre-Teichmann et al. 1997), often making up the largest proportion of bivalve samples (e.g. Linse 2006) and species exhibit great variation in brooding habits (Hain and Arnaud 1992). 
The philobryid bivalve Adacnarca nitens Pelseneer 1903 broods its offspring in clusters within the infrabranchial chamber. Eggs are surrounded by a vitelline membrane (Burne 1920; Soot-Ryen 1951; Dell 1964; Hain and Arnaud 1992) and a large brood size up to 55-75 "embryos" has been reported (Nicol 1967; Hain and Arnaud 1992). A. nitens is eurybathic, found from 8 to 2,350 $\mathrm{m}$ (Aldea et al. 2008), although maximum abundance occurs at shelf depths (Absher et al. 2001; Aldea et al. 2008). It has a circum-Antarctic distribution and like many philobryids, it is endemic to the Antarctic. This species is found attached via byssal threads to various substrates, including rocks (Bowden 2005) hydrozoans, bryozoans, sponges (Dell 1964), ascidians (Soot-Ryen 1951), gorgonaceans (Nicol 1966) and the spines of echinoids (Mortensen 1909).

To date, only little attention has been given to the reproductive ecology and growth in Antarctic molluscs. Comprehensive life history traits are known for a few
Antarctic bivalve species only (e.g. Morton 1978; Richardson 1979; Brey and Hain 1992). More detailed studies, from a wider selection of species are needed to advance our understanding of reproductive trade-offs in Antarctic marine invertebrates.

\section{Materials and methods}

\section{Sample collection}

Specimens of A. nitens were found attached to a mass of hydrozoan (Fig. 1a), dredged at $84 \mathrm{~m}$ off Cape Hallett in the Ross Sea $\left(72^{\circ} 17.2^{\prime} \mathrm{S}, 170^{\circ} 17.9^{\prime} \mathrm{E}\right)$ as a part of the Italian Antarctic sampling programme of the R/V Italica in 2004 (Rehm et al. 2006). All dredged material was fixed in $4 \%$ buffered formalin and transferred into $70 \%$ ethanol for storage after initial sorting. A total of 1,334 A. nitens were collected from the single mass of an unidentified
Fig. 1 Adacnarca nitens. a Adult specimens attached to hydrozoan via byssal threads (bt); b open individual displaying early oocytes $(e o)$ in gonadal tract and advanced veligers (av) in mantle cavity; c advanced oocytes $(a o)$, denticulate plates $(d p)$; d co-occurance of egg $(e)$, midstage veliger $(m v)$ and advanced veligers $(a v)$ in a single dissected cluster; e dissected embryos attached by a twisted vitelline membrane $(\mathrm{vm})$ chord; f cluster of advanced veligers (av) dissected from mantle cavity
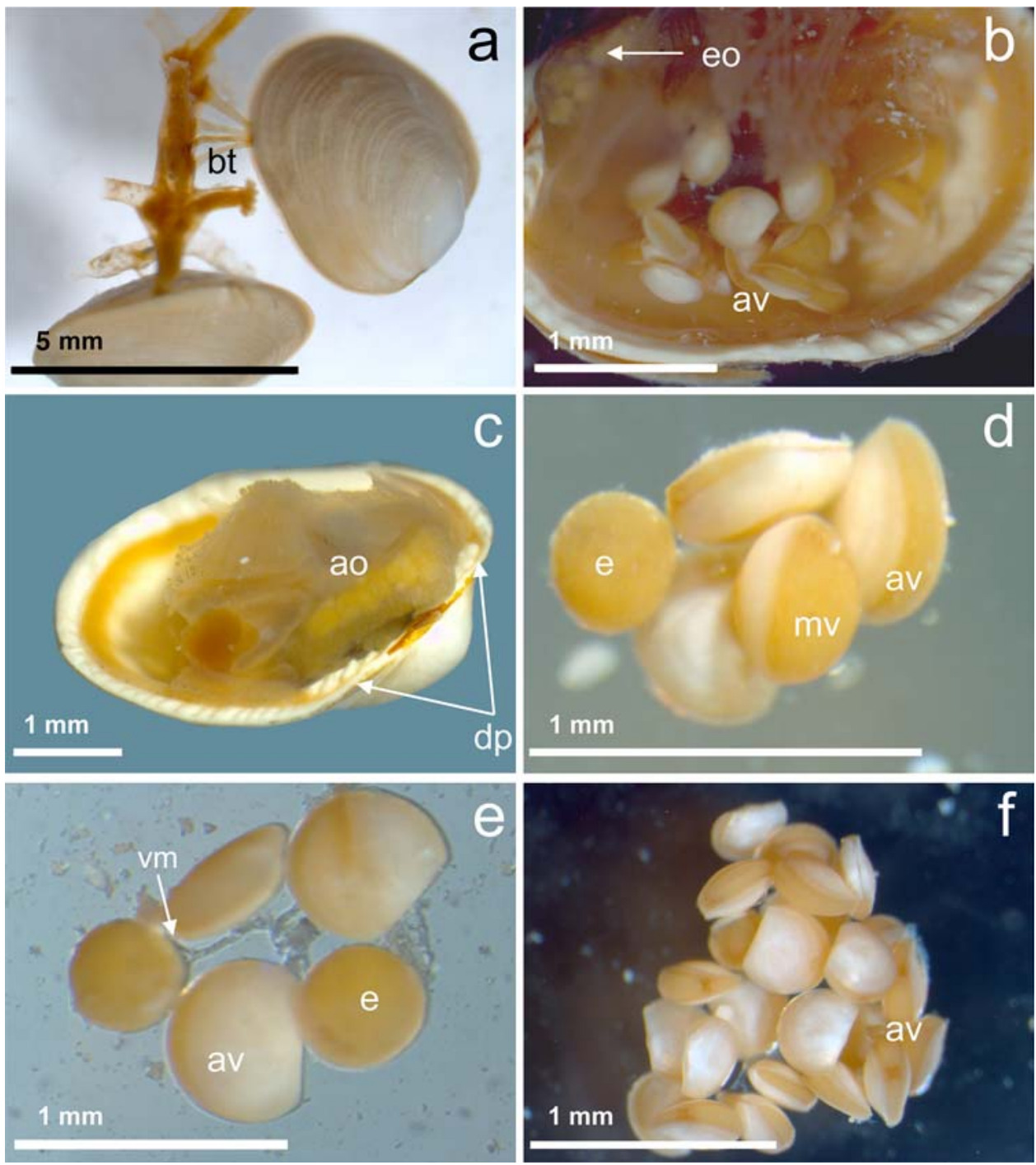
hydrozoan. Specimens were distinguished from Adacnarca polarsterni (Egorova 2003) by their uneven denticulate plates (see Fig. 1c) and their broad, brown byssal threads (Fig. 1a, c).

Population structure and growth

Individual size was measured as the maximum distance across the shell to a precision of $\pm 0.025 \mathrm{~mm}$, using a stereomicroscope. Corresponding growth rings were counted by eye, defined as thin dark lines that delineated two thicker and lighter bands (Clark 1974). Only rings that could be traced around to the prodissoconch were counted. Growth was estimated based on the assumption that growth bands are laid down annually (Picken 1980; Brey and Hain 1992; Heilmayer et al. 2005), allowing a relationship between size and age to be determined. Size and growth rings for 603 randomly selected individuals were recorded. The special von Bertalanffy growth model was fitted to the size-at-age data pairs using a non-linear iterative algorithm defined by the equation:

$H_{t}=H_{\infty}\left(1-\mathrm{e}^{-K\left(t-t_{0}\right)}\right)$

where $H_{\mathrm{t}}$ is the length, $H_{\infty}$ is the mean asymptotic length, $K$ is the Brody growth coefficient (speed of growth), $t$ the age and $t_{0}$ is theoretical age at which shell height equals zero.

\section{Brooding}

Individuals of various sizes were opened to check for evidence of brooding (Fig. 1a-c). Brooding females were measured under a binocular microscope using a scaled eyepiece and the clutch size recorded. The size of each embryo (sensu Hain and Arnaud 1992), from randomly selected clutches $(n=8)$, was measured as the length along the anterior-posterior axis. Brooded embryos were categorised into four stages based on their morphology as follows:

Stage I: unshelled egg [Fig. 2b (left); Burne 1920].

Stage II: first appearance of the shell; prodissoconch (early veliger; Fig. 2c).

Stage III: embryos with developing shell (mid-stage veliger; Fig. 2d, e).

Stage IV: valves have completely enveloped the body mass and are nearly closed [advanced veliger; Fig. $2 b$ (right)].

\section{Histology}

Twenty-two individuals between 2.3 and $6.0 \mathrm{~mm}$ shell length were used for histological analysis. The small size of the bivalves necessitated the sectioning of the entire animal rather than the dissected gonads. To remove valves, individuals were placed in decalcifying solution (hydrocholoric acid) for approximately $1 \mathrm{~min}$ until effervescence had stopped. The tissue was dehydrated in graded alcohols, cleared in histoclear and embedded in $10 \times 10 \mathrm{~mm}$ wax blocks. Sections of $7 \mu \mathrm{m}$ were cut, mounted onto slides and stained with haemotoxylin and counter stained with eosin. Image analyses of reproductive features were captured using the SigmaScan Pro 4 software with feret diameter used to measure the size of oocytes. Spermatogenesis was described from observations of sections through the testis.

\section{Results}

Population structure and growth

Individuals ranged in size from 0.85 to $6.00 \mathrm{~mm}$ and were found with up to eight identifiable growth rings. The population of $A$. nitens displayed a log-normal sizefrequency distribution (Fig. 3), with the 1.50-1.99 mm size class containing the greatest number of individuals. A log-normal 3-parameter curve was fitted to the sizefrequency data:

$y=255.18 \mathrm{e}^{\left[-0.5\left(\frac{\ln \left(\frac{x}{1.99}\right)}{0.496}\right)^{2}\right]}$.

The 603 size-at-age data pairs obtained from growth band readings were best fitted by a special von Bertalanffy equation (Fig. 4):

$H_{t}=6.00\left(1-\mathrm{e}^{-0.215(t+1.469)}\right) R^{2}=0.809$.

Accordingly, the largest individual $(H=6.00 \mathrm{~mm})$ found was about 20 years old.

\section{Gametogenesis and early ontogeny}

Males and females were observed over the entire studied size range and gonads varied in maturity (Figs. 1c, 5a-d). There was no evidence of hermaphroditism. Both brooding and non-brooding females had developing oocytes. The smallest female found to contain oocytes was $2.3 \mathrm{~mm}$ in length. Oocytes varied in size between females and within each female (Fig. 5a, b), displaying a wide range of maturity. In a single individual, oocytes varied in size between 15.1 and $38.9 \mu \mathrm{m}$ (feret diameters) and the largest oocyte measured in any female was $39.5 \mu \mathrm{m}$. The oocytes were not spherical, but irregularly shaped, even when fully grown (Figs. 1c, 2a). Nutritive tissue was also observed surrounding the developing oocytes (Fig. 5b). Testes were observed in individuals at 2.3-6 mm and showed variation in ripeness. A mature testis was observed in an individual 
Fig. 2 Adacnarca nitens.

Embryonic stages, dissected. a Advanced oocytes dissected from gonadal tract; $\mathbf{b}$ early egg (left) advanced veliger, oblique view (right); c dissected cluster of early veligers with prodissoconch; d veliger with developing shell, oblique view; e veliger with developing shell, lateral view; $\mathbf{f}$ cluster of advanced veligers, various angles
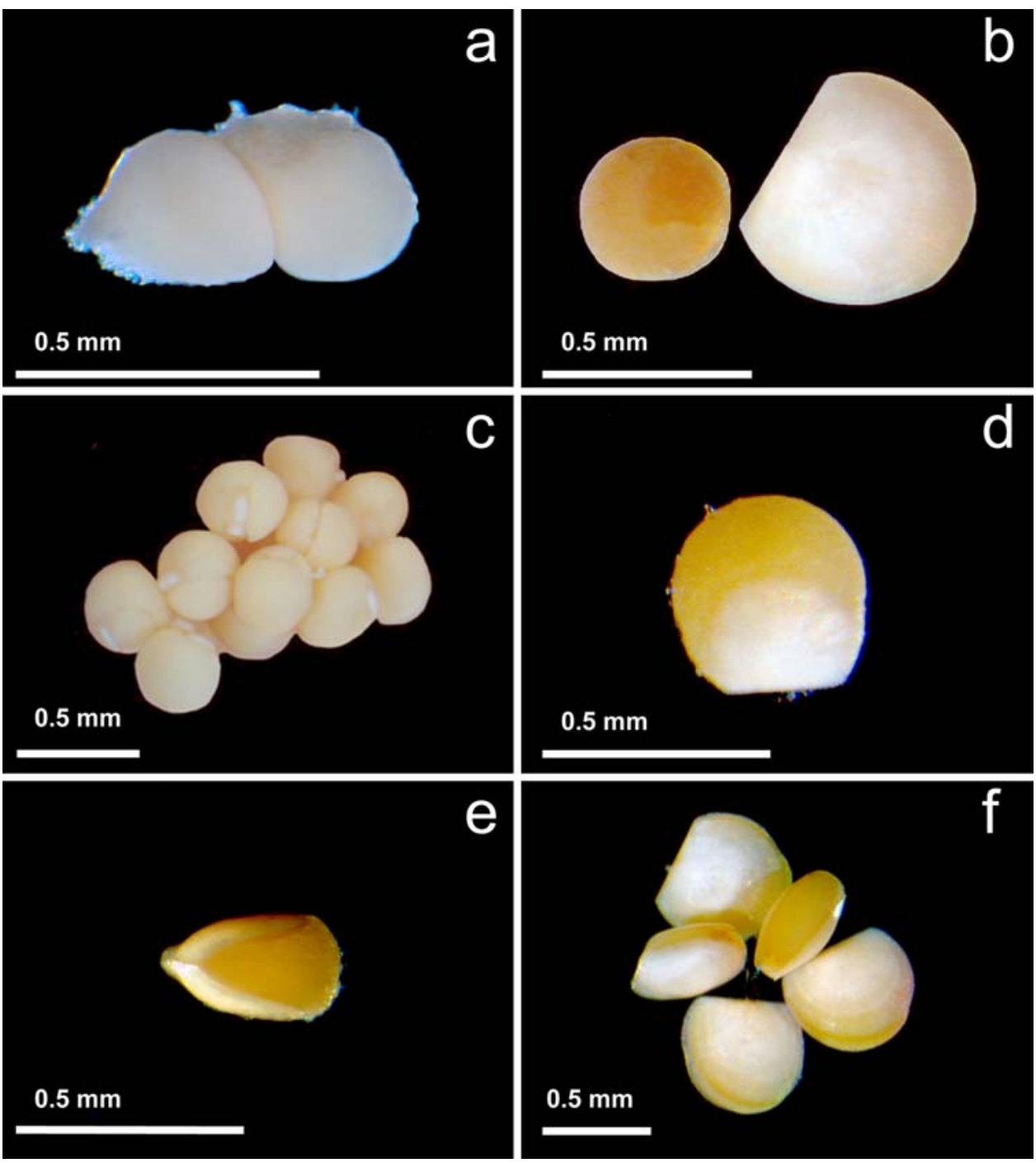

of $2.3 \mathrm{~mm}$ with sperm filling the gonoduct (Fig. 5c). Another male (5 mm length) had an immature testis (Fig. 5d).

\section{Brooding}

In total $23 \%(n=19)$ of the 82 dissected females were found to be brooding young in the mantle cavity anterior of the gills (Fig. 1b) and shell size in brooding females ranged from 3.9 to $5.8 \mathrm{~mm}$. Brood size for individual females ranged from 16 to 52 and was found to significantly correlate with female size $(n=19$; Spearman Rank correlation, $P<0.05)$. Embryos occurred in clusters (Fig. 1d-f), with each embryo being joined to each other by a ramulose twisted chord (Fig. 1e). The eggs were encapsulated in a vitelline membrane, which appeared to be missing following the development of a shell, although embryos still remained

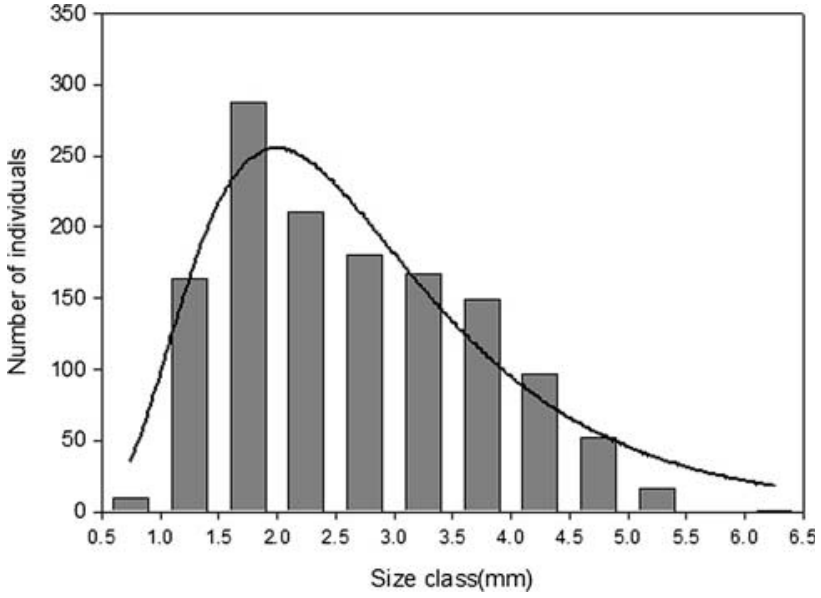

Fig. 3 Adacnarca nitens. Size-frequency distribution in the population studied with fitted log-normal curve: $y=255.18 \mathrm{e}\left[-0.5\left(\frac{\ln \left(\frac{x}{1.99}\right)}{0.496}\right)^{2}\right]$ 


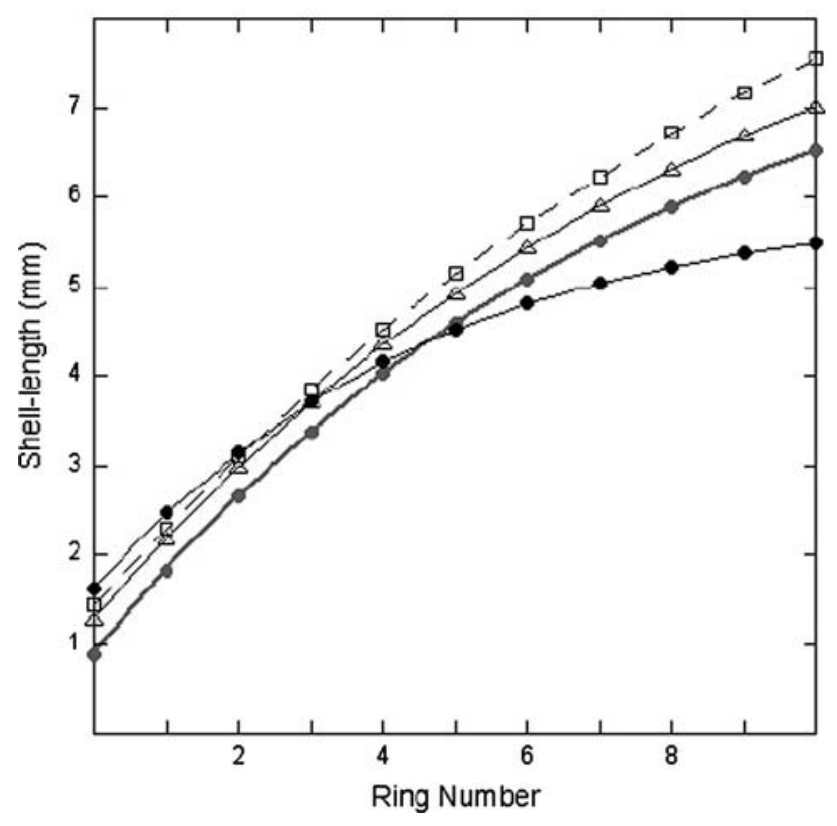

Fig. 4 Growth curves for different phylobryid bivalves and locations around Antarctica. Black dots Adacnarca nitens (Cape Hallett, Ross Sea, this study); Grey Dots, Lissarca miliaris (Signy Island; Richardson 1980); Square, Lissarca notorcadensis (South Shetland/ South Orkney population; Brey and Hain 1992); Open triangle Lissarca notorcadensis (Weddell Sea; Brey and Hain 1992)

attached to the chord. In some females, embryos were at the same stage of development (Fig. 1f), whereas in others, embryos at several different developmental stages were brooded simultaneously (Fig. 2d, e).

Prior to release into the mantle cavity, developing eggs were still irregularly shaped and joined together (Fig. 2a). The embryos at the egg stage (Fig. 2b, left) were spherical with a diameter of $0.38 \mathrm{~mm}(n=3)$. There was only one observation of stage II embryos in dissected specimens (Fig. 2c). Because the development of the prodissoconch affects the shape of the embryo, the 11 early veligers measured were all smaller than the unshelled embryo (see also Fig. 6), with mean length of $0.35 \mathrm{~mm}(\mathrm{SD}=0.015)$. The height of the valves was much greater than their length at this stage, but the early shell eventually changed from an oval shape to a ' $D$ ' shape, where the length of the shell became greater than its height, starting to envelop the body mass of the embryo (Fig. 2d, e). Mid-stage veligers (Fig. 2d-f) increased in size up to about $0.55 \mathrm{~mm}$. The embryos reached the late veliger stage (Fig. 2b, f) at a mean length of $0.58 \mathrm{~mm}(n=21, \mathrm{SD}=0.018)$, with the largest brooded individual reaching $0.61 \mathrm{~mm}$ in length (Fig. 6h). Size-frequency distributions of some clutches showed distinct cohorts of embryos (Fig. 6b, e, g), whilst others appeared to be made up of a continuum sizes and embryonic stages (Fig. 6a, c, d, f). The standard deviation of embryo sizes in each clutch varied from 0.015 to 0.051 .

\section{Discussion}

Population structure and growth

It is assumed that the specimens of A. nitens studied here represent a single population of the epifaunal species, since all of the specimens were taken from a single hydrozoan mass. The lack of larger individuals may be the result of detachment during trawling, predation of larger animals, or the natural detachment of older individuals. Both previous records of larger individuals (reported size maximum $=8 \mathrm{~mm}$ in Hain and Arnaud 1992; Cattaneo-Vietti et al. 2000) came from sampling using grab, which would be less likely to detach individuals than does trawling.

The A. nitens population obtained from single hydrozoan displays a unimodal peak in size structure, which is indicative of non-periodic recruitment to a population (Cerrato 1980). The large proportion of smaller size classes suggests high recruitment to the population. Brooding in this species likely implies that many of the juveniles are not dispersed, but recruited to the local population (Burne 1920).

The slight variation in the size-at-age data, especially in the two youngest age groups, is likely the result of the variable state of shell preservation observed between individuals. In many shells, the periostracum was flaked or absent and many shells showed external damage, leading to an underestimation of rings for some specimens. This removal of growth rings because of "preservation peculiarities" was also noted by Richardson (1979) for Lissarca miliaris. Despite this variability, a common plot (Fig. 4), of all available growth curves of relative epifaunal Antarctic bivalve species demonstrates that all growth models form a rather dense cluster of quite similar curves, i.e. A. nitens is slower growing than the shelf species Lissarca notorcadensis, but faster growing than the shallow water L. miliaris (Fig. 4).

\section{Gametogenesis and development}

The variation in oocyte maturity within and between females (Fig. 6a, b) provides evidence of reproductive asynchrony in A. nitens. This is further exemplified by the different degree of testicular ripeness observed between males (Fig. 5c, d). The presence of developing oocytes in brooding females is consistent with the findings of Brey and Hain (1992) in L. notorcadensis and together with the variable sizes of oocytes, suggests that reproduction is continuous. We did not find any evidence of hermaphroditism in A. nitens.

The sample was collected towards the end of the summer phytoplankton bloom, when primary production would still be high (Smith et al. 2000). The tests of diatoms were 
Fig. 5 Adacnarca nitens.

Gonad histology and gametogenesis. a vitellogenic oocytes $(v o)$ of various developmental stages; b oocytes (o) surrounded by nutritive cells $(n c)$; $\mathbf{c}$ testis and duct $(d)$, showing spermatocytes $(s d)$, spermatogonia $(s g)$ and spermatids $(s t)$;

d spermatagonia $(s g)$ and spermatocytes $(s d)$ with visible tails $(t)$. Scale bars $100 \mu \mathrm{m}$; stained with haematoxylin and eosin
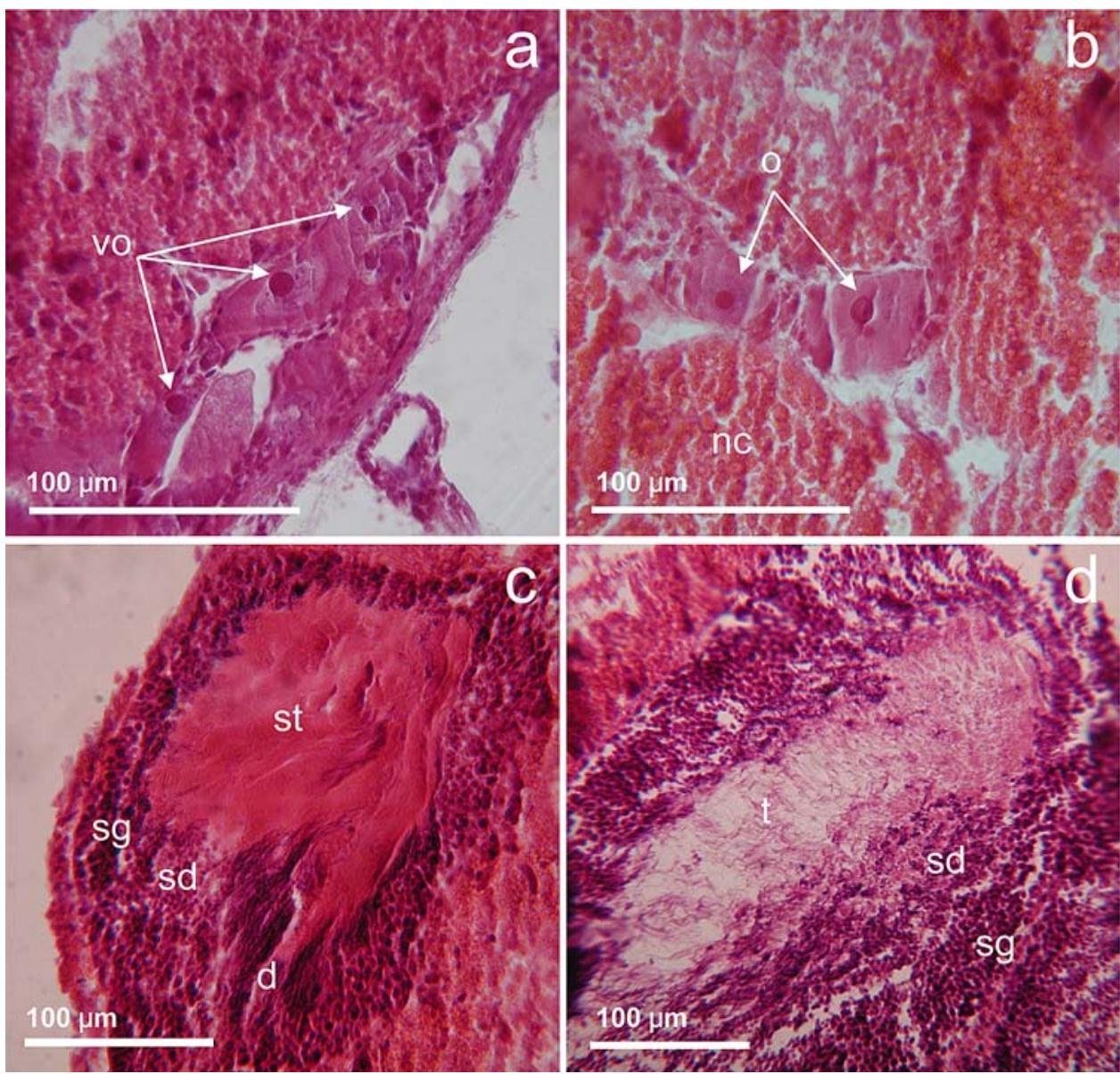

evident in the gut in many of the sections indicating that the animals had recently ingested phytoplankton. Not only was this feeding directly fuelling reproduction and growth, but it may provide a source of energy throughout the winter months when food supply is greatly reduced (Heilmayer et al. 2005). Tissues surrounding the gonads were found to contain high concentrations of nutrients, presumably lipids (Fig. 5b), which may act as an energy store and support oocyte development throughout the periods of reduced food availability to adults.

\section{Brooding}

The strongest evidence of non-periodic reproduction comes from the brooding traits observed in A. nitens. Females were simultaneously brooding embryos at several different stages, attached to a single chord (Fig. 1d, e). Comparisons between broods showed no uniformity of developmental stage (Fig. 6), further precluding the likelihood of gamete release periodicity. A number of females appeared to be brooding young in specific cohorts indicating that reproduction may be sporadic or semi-continuous and the significant correlation of brood size and female size indicates that larger females can invest more energy into reproduction. The degree to which reproductive output is sporadic or continuous shows considerable variation between individuals, which can be seen in the different standard deviation values for embryo size in different clutches (Fig. 6). This variation may simply reflect intraspecific variability in fitness or reproductive output. Such variability may also be habitat site-specific in terms of hydrography and/or food availability, and explain differences in adult growth patterns among populations (Fig. 4; Richardson 1979; Brey and Hain 1992).

Whilst most philobryids appear to brood their young, species vary in terms of egg size, fecundity and the length of retention of the veligers (Hain and Arnaud 1992). Morton (1978) also notes the brooding of fertilised eggs in the infra-branchial chamber of Philobrya munita, and postulates that fertilisation occurs internally in the mantle cavity following inhalation of sperm by the female. We suggest that fertilisation occurs by a similar mechanism in A. nitens, although this could not be directly discerned from histological sections or observation.

Eggs are extruded into the mantle cavity at a diameter of $0.38 \mathrm{~mm}$ (Fig. 6f), whereas the eggs of L. notorcadensis are retained in the ovaries up to $0.7 \mathrm{~mm}$ (Fig. 4 in Brey and Hain 1992). The development of the prodissoconch 
Fig. 6 Size-class distribution of brooded embryos/veligers dissected from eight adult specimens of Adacnarca nitens. For developmental stage classification, see "Materials and methods". Asterisk: single unfilled column (in $\mathbf{f}$ ) denotes single record of stage I embryo. Note that early veligers (stage II) are smaller than unshelled embryos (stage I), as the development of the prodissoconch affects the shape of the developing veliger. $\sigma$, standard deviation of embryo sizes in each clutch

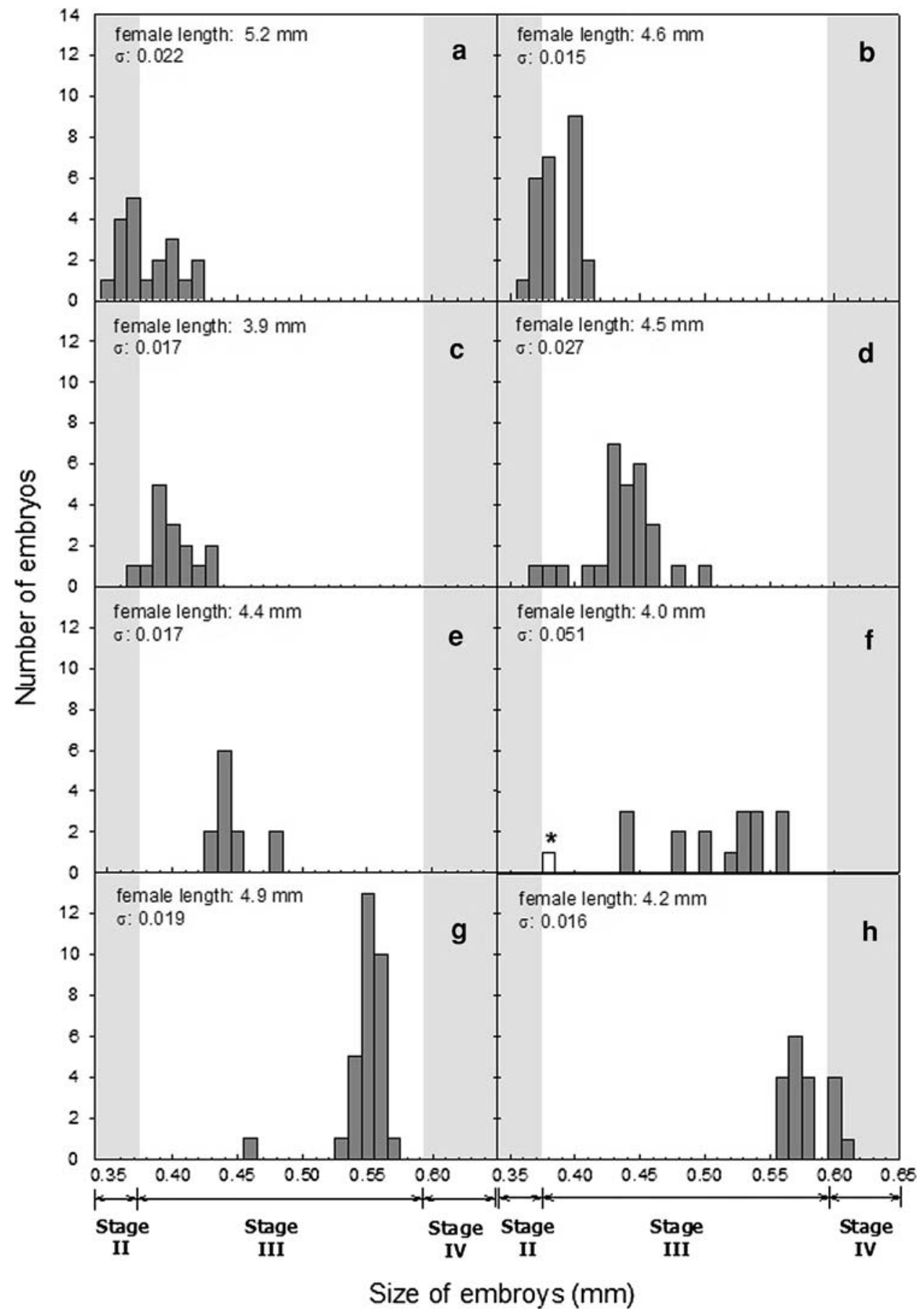

represents the second ontogenetic stage and as the shell increases in size, it eventually reaches and exceeds the starting diameter of the egg (mid-stage veliger).

Once growth of the shell has encased the body mass of the embryo and the valves are near closure, the embryo enters the advanced veliger stage (Fig. 2b, right side). This final stage indicates that the embryo is ready for release. While the largest advanced veliger measured here was $0.61 \mathrm{~mm}$, Hain and Arnaud (1992) record embryos at
$0.84 \mathrm{~mm}$ in size. This must be the upper limit of brood retention, as the smallest juveniles found attached to the substrate in this study were $0.85 \mathrm{~mm}$ in length. This would suggest that at least a portion of juveniles remain attached to the same substrate as the mother, recruiting to the local population. The juveniles may even pass directly from the parent onto the substrate. Morton (1978) found juveniles of $P$. munita attached to the parental byssus both within and outside of the mantle cavity. 
Dispersal

Brooding in A. nitens suggests a local release of juveniles and thus a hampered dispersal of young over long distances (Mileikovsky 1971); yet this species and many others that brood their young have circum-Antarctic distributions (Dell 1990; Pearse et al. 1991). The most likely dispersal mechanism for this benthic brooding bivalve is rafting, although bivalves have also been found alive after passing through the gut of the notothenioid fish, Notothenia coriiceps (Domaneschi et al. 2002), providing another potential means of dispersal. The possibility of rafting dispersal in the Antarctic was tested by Highsmith (1985) and observed by Helmuth et al. (1994) for the brooding pelecypod bivalve Gaimardia trapesina. Dell (1972) first proposed rafting to explain the wide distributions of brooders in the Antarctic, commenting that dispersal success should be "easy enough" for the philobryids, owing to their habit of attachment to other organisms. However, the primary benefit of this habit is not dispersal, but likely the superior access to the limited food supply afforded by elevating themselves above the crowded benthos (Dell 1972).

The potential for successful range expansion by rafting is high for brooders, as a new area could be colonised by just a single female with a large clutch of brooded young as a "seed population". The successful establishment of such population is even higher for species, such as A. nitens, that continuously reproduce. Pearse and Lockhart (2004) conclude that "however unlikely rafting of benthic brooders may be, it is far more likely to occur, and occur successfully, in the Antarctic than elsewhere, because of the unique oceanographic and geological conditions afforded by the (Antarctic circumpolar current) over the past 20-30 million years". These authors hypothesise that the development of the ACC facilitated the speciation of brooding clades through rafting. Because of its epifaunal life style, ice scouring might play an important role in getting A. nitens assemblages, including their biotic substrate, afloat (Gutt 2007).

The current eurybathy displayed by A. nitens and the dispersal capabilities afforded by rafting would have allowed it to survive the last glacial period through migration into the deep sea (Brey et al. 1996) or through migration around temporarily open shelf refuges (Thatje et al. 2005). The attachment habit of $A$. nitens and the high degree of care given by brooders would give them a selective advantage over species with planktotrophic larvae in the food-limited glacial conditions (Poulin et al. 2002; Heilmayer et al. 2008; Thatje et al. 2005, 2008).

This hypothesis and that of Pearse and Lockhart (2004) begin to answer Dell's question (1972) as to why brooding provides an adaptational advantage to some Antarctic fauna. The potential for detailed autecological studies to shed light on important problems is exemplified here in the case of $A$. nitens, while application of molecular tools will allow further analysis of radiation and extinction processes in the philobryids. It is only through detailed studies of other benthic invertebrate species that these hypotheses can be tested and our understanding of the evolutionary history of Antarctic benthic fauna increased.

Acknowledgments N.D. Higgs and A.J. Reed equally contributed to this work. The authors express their thanks to Peter Rehm and the members and crew of the Italian R/V Italica expedition for collection of samples. Katrin Linse is thanked for confirming the species identification. This project was supported by the Marine Biodiversity and Ecosystem Functioning Network of Excellence, MarBEF (Contract no. GOCE-CT-2003-505446) of the 6th European Framework Programme (FP6).

\section{References}

Absher TM, Boehs G, Ritzmann Feijo A, Trevisan DS, Filho OAN (2001) Depth distribution of benthic bivalve molluscs from Admiralty Bay, King George Island, Antarctica. In: SalviniPlawen L, Voltzow J, Sattmann H, Steiner G (eds) World Congress of Malacology 2001. Unitas Malacologica, Viennia, p 417

Aldea C, Olabarria C, Troncoso JS (2008) Bathymetric zonation and diversity gradient of gastropods and bivalves in West Antarctica from the South Shetland Islands to the Bellingshausen Sea. Deep Sea Res Part I Oceanogr Res Pap 55:350-368. doi:10.1016/j.dsr. 2007.12.002

Arntz WE, Gili JM (2001) A case for tolerance in marine ecology: let us not put out the baby with the bathwater. Sci Mar 65:283-299. doi:10.3989/scimar.2001.65s2283

Arntz WE, Gutt J, Klages M (1997) Antarctic marine biodiversity: an overview. In: Battaglia B, Valencia J, Walton DWH (eds) Antarctic communities: species, structure and survival. Cambridge University Press, Cambridge, pp 3-14

Bowden DA (2005) Seasonality of recruitment in Antarctic sessile marine benthos. Mar Ecol Prog Ser 297:101-118. doi:10.3354/ meps 297101

Brey T, Hain S (1992) Growth, reproduction and production of Lissarca notorcadensis (Bivalvia: Philobryidae) in the Weddell Sea, Antarctica. Mar Ecol Prog Ser 82:219-226. doi:10.3354/ meps082219

Brey T, Dahm C, Gorny M, Klages M, Stiller M, Arntz WE (1996) Do Antarctic benthic invertebrates show an extended level of eurybathy? Antarct Sci 8:3-6. doi:10.1017/S0954102096000028

Burne RH (1920) Mollusca-Part IV. Anatomy of Pelecypoda. Nat Hist Rep Br Antarct Terra Nova Exped 2:233-256

Cattaneo-Vietti R, Chiantore M, Schiaparelli S, Albertelli G (2000) Shallow and deep-water mollusc distribution at Terra Nova Bay (Ross Sea, Antarctica). Polar Biol 23:173-182. doi:10.1007/ s003000050024

Cerrato RM (1980) Demographic analysis of bivalve populations. In: Rhoads DC, Lutz RA, Stehli FG (eds) Skeletal growth of aquatic organisms: biological records of environmental change. Plenum Press, New York, pp 417-465

Clark GR (1974) Growth lines in invertebrate skeletons. Annu Rev Earth Planet Sci 2:77-99. doi:10.1146/annurev.ea.02.050174. 000453

Dell RK (1964) Antarctic and subantarctic mollusca: amphineura, scaphopoda and bivalvia. Discov Rep 33:99-250

Dell RK (1972) Antarctic Benthos. In: Russell FS, Yonge M (eds) Advances in marine biology, vol X. Academic, London, pp 1-216 
Dell RK (1990) Antarctic mollusca: with special reference to the fauna of the Ross Sea. R Soc N Z Bull 27:1-311

Domaneschi O, da Silva J, Neto LRP, Passos FD (2002) New perspectives on the dispersal mechanisms of the Antarctic brooding bivalve Mysella charcoti (Lamy, 1906). Polar Biol 25:538-541. doi:10.1007/s00300-002-0379-6

Egorova EN (2003) New species of the genus Adacnarca (Bivalvia, Philobryidae) from Antarctica. Zool Zh 82:771-780

Emlet RB (1990) World patterns of developmental mode in echinoid echinoderms. In: Hoshi M, Yamashita O (eds) Advances in invertebrate reproduction. Elsevier, Amsterdam, pp 329-335

Gallardo CS, Penchaszadeh PE (2001) Hatching mode and latitude in marine gastropods: revisiting Thorson's paradigm in the southern hemisphere. Mar Biol (Berl) 138:547-552. doi:10.1007/ s002270000477

Galley EA, Tyler PA, Clarke A, Smith CR (2005) Reproductive biology and biochemical composition of the brooding echinoid Amphipneustes lorioli on the Antarctic continental shelf. Mar Biol (Berl) 148:59-71. doi:10.1007/s00227-005-0069-3

Gutt J (2007) Antarctic macro-zoobenthic communities: a review and an ecological classification. Antarct Sci 19(2):165-182. doi: $10.1017 /$ S0954102007000247

Hain S, Arnaud PM (1992) Notes on the reproduction of highAntarctic molluscs from the Weddell Sea. Polar Biol 12:303312. doi:10.1007/BF00238273

Heilmayer O, Honnen C, Jacob U, Chiantore MC, Cattaneo-Vietti R, Brey $\mathrm{T}$ (2005) Temperature effects on summer growth rates in the Antarctic scallop, Adamussium colbecki. Polar Biol 28:523527. doi:10.1007/s00300-005-0716-7

Heilmayer O, Thatje S, McClelland C, Conlan K, Brey T (2008) Changes in biomass and elemental composition during early ontogeny of the Antarctic isopod crustacean Ceratoserolis trilobitoides. Polar Biol 31:1325-1331. doi:10.1007/s00300008-0470-8

Helmuth B, Veit RR, Holberton R (1994) Long-distance dispersal of a sub-Antarctic brooding bivalve (Gaimardia trapesina) by kelp rafting. Mar Biol (Berl) 120:421-426. doi:10.1007/BF00680216

Highsmith RC (1985) Floating and algal rafting as potential dispersal mechanisms in brooding invertebrates. Mar Ecol Prog Ser 25:169-179. doi:10.3354/meps025169

Jarre-Teichmann A, Brey T, Bathmann UV, Dahm C, Dieckmann GSG M, Klages M, Pagès F, Plötz J, Schnack-Schiel SB, Stiller M, Arntz WE (1997) Trophic flows in the benthic shelf community of the eastern Weddell Sea, Antarctica. In: Battaglia B, Valencia J, Walton DWH (eds) Antarctic communities: species, structure and survival. Cambridge University Press, Cambridge, pp 118-134

Linse K (2006) New records of shelled marine molluscs at Bouvet Island and preliminary assessment of their biogeographic affinities. Polar Biol 29:120-127. doi:10.1007/s00300-005-0721-x

Mileikovsky SA (1971) Types of larval development in marine bottom invertebrates, their distribution and ecological significance: a re-evaluation. Mar Biol (Berl) 10:193-213. doi:10.1007/ BF00352809

Mortensen T (1909) Die Echinoiden der deutschen Südpolar Expedition, 1901-1903. In: Drygalski E (ed) Deutsche Südpolar Expedition 1901-1903, vol XI: 1-113
Morton B (1978) Biology and functional-morphology of Philobrya munita (Bivalvia Philobryidae). J Zool 185:173-196

Nicol D (1966) Descriptions, ecology and geographic distribution of some Antarctic pelecypods. Bull Am Paleontol 51:1-102

Nicol D (1967) Some characteristics of cold-water marine pelecypods. J Paleontol 41:1330-1340

Pearse JS, Lockhart SJ (2004) Reproduction in cold water: paradigm changes in the 20th century and a role for cidaroid sea urchins. Deep Sea Res Part II Top Stud Oceanogr 51:1533-1549. doi: 10.1016/j.dsr2.2004.06.023

Pearse JS, McClintock JB, Bosch I (1991) Reproduction of Antarctic benthic marine-invertebrates-tempos, modes, and timing. Am Zool 31:65-80

Pelseneer P (1903) Mollusques (Amphineures, Gastropodes et Lamellibranches). In: Rés Voy SY Belgica en 1897-1899. Zoologie, 6-9. J.E. Buschmann, Anvers, pp 1-85

Picken GB (1980) Reproductive adaptations of Antarctic benthic invertebrates. Biol J Linn Soc Lond 14:67-75. doi:10.1111/j. 1095-8312.1980.tb00098.x

Poulin E, Palmer AT, Fral JP (2002) Evolutionary versus ecological success in Antarctic benthic invertebrates. Trends Ecol Evol 17:18-221. doi:10.1016/S0169-5347(02)02493-X

Ramirez Llodra E (2002) Fecundity and life-history strategies in marine invertebrates. Adv Mar Biol 43:87-170. doi:10.1016/ S0065-2881(02)43004-0

Rehm P, Thatje S, Arntz WE, Brandt A, Heilmayer O (2006) Distribution and composition of macrozoobenthic communities along a Victoria-Land Transect (Ross Sea, Antarctica). Polar Biol 29:782-790. doi:10.1007/s00300-006-0115-8

Richardson MG (1979) The ecology and reproduction of the brooding Antarctic bivalve Lissarca miliaris. Br Antarct Surv B 49:91-115

Ripley BJ, Caswell H (2008) Contributions of growth, stasis, fitness and reproduction in brooding and broadcast spawning marine bivalves. Popul Ecol 50:207-214. doi:10.1007/s10144-0080075-7

Smith WO, Marra J, Hiscock MR, Barber RT (2000) The seasonal cycle of phytoplankton biomass and primary productivity in the Ross Sea, Antarctica. Deep Sea Res Part II Top Stud Oceanogr 47:3119-3140. doi:10.1016/S0967-0645(00)00061-8

Soot-Ryen T (1951) Antarctic Pelecypods. Sci Res Nor Antarct Exped 1927-1928(32):1-46

Thatje S, Schnack-Schiel S, Arntz WE (2003) Developmental tradeoffs in subantarctic meroplankton communities and the enigma of low decapod diversity in high southern latitudes. Mar Ecol Prog Ser 260:195-207. doi:10.3354/meps260195

Thatje S, Hillenbrand CD, Larter R (2005) On the origin of Antarctic marine benthic community structure. Trends Ecol Evol 20:534540. doi:10.1016/j.tree.2005.07.010

Thatje S, Hillenbrand CD, Mackensen A, Larter R (2008) Life hung by a thread: endurance of Antarctica fauna in glacial periods. Ecology 89:682-692. doi:10.1890/07-0498.1

Vance RR (1973) Reproductive strategies in marine benthic invertebrates. Am Nat 107:339-352. doi:10.1086/282838 